\title{
Bipolar Disorder and Adult Attention Deficit/ Hyperactivity Disorder: The Same or Different?
}

\author{
Elif Karaahmet ${ }^{1}$, Gökay Alpak²
}

ÖZET:

Popüler konu: iki uçlu mizaç bozuklug̃u ve erișkin dikkat eksikliãi hiperaktivite bozuklug̃u ne kadar birlikte ne kadar ayrı?

iki Uçlu Mizaç Bozuklug̃u (iUMB) ve Dikkat Eksiklig̃i Hiperaktivite Bozuklug̃u (DEHB) sıklıkla bir arada bulunabilen tanılardır. Her iki bozuklug̃un da Eksen I ve Eksen II tanılarla ekhastalık oranları yüksektir. Örtüsen belirtiler ve iki bozuklug̃un bir arada görülme ihtimali son yıllarda giderek artan bir șekilde bu iki durumun birbirinin öncülü veya öncül belirtileri olup olmadıg̃ı sorusunu gündeme getirmiştir ve aralarındaki olası ilişki tüm yaș gruplarında giderek daha fazla dikkat çekmektedir. iUMB/DEHB ekhastalıg̃ı hastalıg̃ın seyrini olumsuz etkilemekte, iyilik dönemlerini kısaltmakta, olumsuz yasam olaylarına maruz kalmaya neden olmakta ve yaşam kalitesini bozmaktadır. Ayrıca anksiyete bozuklug̃u ve alkol bag̃ımlıı̃̊nın artmasına neden olmaktadır. Bu iki hastalık arasındaki ilișkiyi anlamaya yönelik çalıșmalar henüz yetersizdir. Bu yazıda IUMB ve Erișkin DEHB ile ilgili benzeșen ve ayrilan yönler epidemiyolojik çalıșmalar, ailesel çalıșmalar ve nörogörüntülenme çalıșmaları eșliāinde gözden geçirilecektir.

Anahtar sözcükler: îki uçlu mizaç bozuklug̃u, dikkat eksikliḡi hiperaktivite bozuklug̃u, ekhastalık

Journal of Mood Disorders 2011;1(3):136-44

\section{ABSTRACT:}

Bipolar disorder and adult attention deficit/ hyperactivity disorder: the same or different?

The diagnoses of Bipolar Affective Disorder (BAD) and Attention Deficit Hyperactivity Disorder (ADHD) can frequently be present concomitantly. The rates of comorbidity of the both disorders with Axis I and Axis II diagnoses are high. Overlapping symptoms and the possibility of observing these two disorders concomitantly have recently arisen the question, whether these two conditions are precursors or precursor symptoms of each other. The possible relationship between them is increasingly drawing attention in all age groups. Comorbidity of BAD/ADHD affects the course of the disease negatively, shortens the periods of well-being, increases exposure to negative life events, and decreases quality of life. It also increases occurrence of anxiety disorder and alcoholism. Currently, studies aimed to understand the relation between these two diseases are inadequate. In this article, similaraties and differences of BAD and Adult ADHD are reviewed according to the findings in epidemiologic studies, familial studies and neuroimaging studies.

Key words: Bipolar affective disorder, attention deficit hyperactivity disorder, comorbidity

Journal of Mood Disorders 2011;1(3):136-44
1Uzm. Dr., Siverek Devlet Hastanesi Siverek, Şanlıurfa-Turkey ${ }^{2}$ Uzm. Dr., Midyat Devlet Hastanesi, Midyat, Mardin-Turkey

Yazıșma Adresi / Address reprint requests to: Elif Karaahmet, Siverek Devlet Hastanesi Şanlurfa Yolu Üzeri 5. Km. Șanlıurfa-Turkey

Telefon / Phone: +90-414-552-1246

Elektronik posta adresi / E-mail address: elifkaraahmet@yahoo.com

Kabul tarihi / Date of acceptance: 5 Eylül 2011 / September 5, 2011

\section{Bag̃ıntı beyanı}

E.K., G.A.: Yazarlar bu makale ile ilgili olarak herhangi bir çıkar çatıșması bildirmemișlerdir.

Declaration of interest:

E.K. G.A. The authors reported no conflict of interest related to this article.

\section{INTRODUCTION}

The relation between bipolar affective disorder (BAD) and adult attention deficit hyperactivity disorder (ADHD) is not clear (1). Higher rate of ADHD symptoms in patients with $\mathrm{BAD}$ and higher rate of BAD in the adulthood in patients with ADHD have increased attention on this subject (2).

The lifelong prevalence of BAD ranges $0.4 \%$ to $1.6 \%$ (mean 1.2\%) $(3,4,5)$. Given that it is considered as bipolar spectrum, this rate exceeds $5 \%(5,6)$. The lifelong rate of comorbidity of BAD which is frequently observed with axis I and axis II diagnoses with axis I disorder is $50-70 \%$. When studies about comorbidity of BAD and ADHD are examined, the rates of association for both disorders decrease as the age gets older, but is observed at a rate of $9-35 \%$ in the adulthood (7-12).

Although community-based longitudinal follow-up studies investigating the prevalence of adult ADHD are limited and composed of indirect data (13), the symptoms of ADHD diagnosed in the childhood continue at a rate of $50-80 \%$ in the adolescence and $30-50 \%$ in the adulthood (14). Studies conducted in different countries indicate the prevalence of Adult ADHD as 1-4.4\% (15-18). Although discussions about Adult ADHD continue, studies show that this disorder is a frequent diagnosis decreasing the functionality $(15,18-20)$. An important property of ADHD is that it has a comorbidity at a rate of $65-89 \%$ in the 
clinical studies conducted (21-23). Studies investigating ADHD comorbidity among these co-diagnoses are limited and their results are controversial. The most common comorbidity is oppositional defiant disorder (24). Also speech and learning disorders and anxiety disorders are frequently observed as comorbidity $(7,23,25)$. The comorbidity rates of ADHD and depression are 10-30\% $(26,27)$. This can be unipolar or bipolar depression. Bipolarity is observed at a rate of $5-20 \%$ in ADHD $(11,28)$. In addition to comorbidity, $\mathrm{BAD}$ and $\mathrm{ADHD}$ have similar and differentiating aspects epidemiologically and clinically. The aim of this article is to examine the possible relation between BAD and ADHD in the adults according to the findings in epidemiologic studies, familial studies, clinical studies and neurobiological studies.

\section{RELATIONSHIP BETWEEN BAD and ADULT ADHD}

\section{Methodological Difficulties}

Although methodological difficulties are present in all the psychiatric disorders, unanswered questions in the differential diagnosis of these two conditions cause to both diagnostic and therapeutical difficulties. There are many separate studies about BAD and ADHD. Although $\mathrm{BAD}$ and $\mathrm{ADHD}$ are considered as two different disorders, they show many similar clinical properties including racing thoughts, hyperactivity, increase in the amount of speech, impulsivity, and attention deficit $(1,29,30)$. In adult ADHD, anger and mood changes are frequently observed; increase in the amount of energy and decrease in need of sleep are present (31). In patients with Adult ADHD, decrease in functionality may be observed which appears to be occasionally episodic; this arises from the fact that ADHD is a condition leading to developmental problems, change in performance and reactivity. Overlapping symptoms and the possibility of observing these two disorders concomitantly have recently arisen the question, whether these two conditions are precursors or precursor symptoms of each other. The possible relationship between them is increasingly drawing attention in all age groups $(32,33)$. In addition to overlapping symptoms, these two conditions have also many different properties. As Wingo and Ghaemi (26) recently emphasized, as the disorder is stable $\mathrm{BAD}$ shows an episodic course. Furthermore, while increased productivity, increase in self-confidence and the presence of psychotic aspects are observed frequently in euphoric $\mathrm{BAD}$, they are rarely observed in ADHD. Excluding the cases starting in the childhood, adequate function has been proved in cognitive tests including writing, reading and different behavioral measurements in the premorbid period in BAD (35), but decrease in functionality is frequently observed in ADHD starting from the childhood (36). It was found that adults with a diagnosis of ADHD showed lower performance in tests which measured selective attention, continuing attention, and suppression of response compared to normal controls. This shows that attention problems in ADHD continue in the adulthood (37).

It is generally not easy to make retrospective examination and differentiation with our current experience to understand the differences related to the courses of the disorders $(32,38)$. Since clinical course is milder and more disorganized, the risk for misdiagnosis is increased especially for BAD-II (39). Temperament properties of the patient or subsyndromal manifestations also increase the risk of misdiagnosis (40).

According to DSM IV, diagnostic categories of BAD and ADHD seem to be unrelated. There is similarity between some ADHD symptoms and manic symptoms. However, it is not fully clears if this relationship is at a superficial level due to clinical definitions or there is an overlapping at biological level (32).

In developmental point of view, ADHD starts in the childhood and shows different symptoms in the adulthood and the symptoms in the childhood are defined for Adult ADHD. BAD usually starts in the adulthood and the form which starts in the childhood displays different clinical properties. For the diagnosis, symptoms observed in the adulthood are evaluated. The diagnoses of Adult ADHD and childhood BAD do not define developmental changes. Therefore, it is difficult to understand the symptomatic similarities and differences of these two conditions.

Prediction of the prevalence of Adult ADHD comorbidity shows a wide range because of the methods used and sampling differences. Overlapping symptoms of BAD and ADHD constitute the most important diagnostic limitation (32). There may be difficulties in remembering the symptoms which had started in the childhood during the adulthood. In a 16-year follow-up study, only $78 \%$ of 
the patients who had ADHD in the childhood could remember the symptoms in the adulthood (41). In addition, the frequency of comorbidity might have been overestimated, since studies were conducted in patients who seek for help (42). When these are considered together, it can not be accurately evaluated which one affects the prediction regarding the prevalence of ADHD to what extent (11).

Disorder course, core symptoms and phenomenology in patients with a comorbidity of ADHD are different compared to patients without a comorbidity of ADHD (7). The disorder starts at an earlier age in BAD patients with a comorbidity of ADHD, depressive and mixed attacks are observed more frequently, euthymic periods are shorter and anxiety disorders and alcohol-substance addiction are observed more frequently compared to patients without a comorbidity of $\operatorname{ADHD}(7,11,23,43)$. Again, in these patients, the quality of life decreases (44), the rates of suicidal attempt and legal problems increase (11) and negative life events are observed more frequently (45).

Despite all these difficulties, three possibilities should be considered, when the literature is examined to understand the nature of the relation between BAD and $\mathrm{ADHD}$; the first possibility is that these two conditions are completely different and have no relation. The second possibility is that these two conditions are two different manifestations of the same condition and the third possibility is that a more complex relation is present as suggested bysome authors in familial and phenomenology studies (32).

In this context, review of epidemiological studies, familial studies, neurobiological studies, and clinical studies, which may help us to understand the relation between BAD and ADHD, can be beneficial for us to comprehend the nature of the subject.

\section{Epidemiological Studies}

Studies show that ADHD in children with BAD is observed at a higher rate $(57-100 \%)$ as compared to patients with BAD in adolescence (46-49). In a different perspective, the rate of $\mathrm{BAD}$ in children with ADHD was found to be 10-fold higher compared to children without ADHD (50). Biederman et al. (51) showed that the diagnostic criteria of both mania and ADHD were maintained in most children with a comorbidity of BAD and $\mathrm{ADHD}$, when overlapping symptoms were excluded. These results noted that there was no diagnostic artifact between ADHD and mania in the childhood despite the same diagnostic criteria. However, this raised controversial subjects. The critics about this subject stated that the diagnoses in this study were not compatible with classical mania and $17 \%$ displayed atypical properties (52). This may lead to increase in the rates of artifact related to the symptoms of BAD and ADHD (53). Therefore, repeated studies about the subject are needed. Another reason for the high rate of comorbidity was suggested by Biederman group (51) and West $(46,47)$; DSM III R criteria used for the diagnosis of BAD do not require time for the diagnosis. However, a period of at least one week is needed in DSM IV. Therefore, it is proposed that mood change may not typically last one week and may lead to falsely high rates of comorbidity in children with ADHD. The rate of ADHD in patients with BAD was found to be $9-97 \%$ and the rate is higher in cases in whom BAD starts in the childhood as compared to the cases in whom BAD starts in the adolescence $(46,48,49)$. Geller at al (48) assessed $60 \mathrm{BAD}$ and $60 \mathrm{ADHD}$ whose ages are 7-16 years old, using with Washington University at St. Louis Kiddie and Young Adult-Schedule for Affective Disorders and Schizophrenia - Lifetime and Present Episode Version-DSM-IV (WASH-U-KSADS). They divided BAD patients in to the prepubertal and postpubertal groups. They found that ADHD occurred in $97.0 \%$ of prepubertal versus $74.1 \%$ of postpubertal BAD cases. Nevertheless, bipolar disorder is also diagnosed in approximately $7-23 \%$ of the children with a diagnosis of ADHD $(54,55)$.

Faranoe et al. (49) reported that the age of onset of BAD is critically important. It is suggested that a heterogeneous structure showing the properties of BAD and ADHD may be a subgroup in the bipolar spectrum and this may be a different familial subtype which classically starts at the adulthood $(43,51,56)$. When the studies about the association of Adult ADHD and BAD are examined, similar findings are observed, although the rates of association are decreased. In the study performed by Tamam et al., lifelong association with ADHD in patients with BAD was found at a rate of $27 \%$ and association of BAD with ADHD continuing in the adulthood was found to be $16 \%$ (7). Similar findings were 
found in other studies $(9-35 \%)(8-12)$. In contrast to the other studies, Jaideep et al. (57) found the rate of ADHD to be low (4\%) in patients with BAD which started in the childhood in a study they performed in 2006. The difference of our study compared to the other studies may be explained by the fact that it was conducted in a small number of patients with BAD. Again, in a study performed in India, a comorbidity of ADHD was not found in 30 children with a diagnosis of BAD (58). Similarly, Kim Cohen et al. (59) compared the histories of ADHD in children with and without mania and no relation were found between mania and ADHD.

Although few studies state the contrary $(58,59)$, the presence of a strong relation between BAD and a comorbidity of ADHD is noted, when the literature is examined (32). Comorbidity of BAD and ADHD may be a separate subtype of ADHD or BAD. Although a diagnostic artifact is possible $(32,46,48,49,54,55)$, most studies show the strength of the relationship.

\section{Familial Studies}

Strong familial relationship is known in both BAD and ADHD (28). BAD was found with a 7-8 fold higher rate in the first-degree relatives of patients with BAD compared to the patients without BAD (60).

In a meta-analysis which evaluated the results of 8 studies conducted in parents of children and adolescents with a diagnosis of $\mathrm{ADHD}$, it was shown that the relative risk for a diagnosis of ADHD was increased 2-8 fold in parents of children and adolescents with a diagnosis of ADHD (61). In a familial study conducted by Wozniak et al. (56), a comorbidity of BAD and ADHD was found at a high rate in children younger than 12 years of age and their first-degree relatives. In the meta-analysis of six studies conducted between 1970 and 1990, the prevalence of BAD in the first-degree relatives of children with ADHD (2.6\%) was compared with the control group (1.3\%) and rates of $\mathrm{BAD}$ in the relatives of these children were found to be high. However, statistically significant difference was not found in any of the studies (62). In a study, the rate of $\mathrm{ADHD}$ was found to be $28 \%$ in 60 children of adult patients with BAD. 9 of these children were reported to have $\mathrm{BAD}$ and $88 \%$ of these were reported to have ADHD (63).

The prevalence of both $\mathrm{BAD}$ and $\mathrm{ADHD}$ was found to be high in the first-degree relatives of children with $\mathrm{BAD}$ $(32,56)$. In addition, ADHD and BAD were found in association in the relative of children with $\mathrm{BAD}$ and $\mathrm{ADHD}$ (49).

Persistence of the symptoms of ADHD in the adulthood, high rate of a comorbidity of ADHD in patients with $\mathrm{BAD}$ and high rate of mood swings in ADHD may be explained by a genetic relation between $\mathrm{BAD}$ and $\mathrm{ADHD}$. Biederman et al. (51) who supported this hypothesis found the rates of ADHD to be also high in families of patients with BAD. However, it is not possible to explain all variations genetically. Many disorders have similar environmental risk factors (64).

In the light of these findings, it can be stated that BAD and ADHD may be disorders related to each other and have similar familial risk factors (32). In addition, the hypothesis that a different type of BAD/ADHD may be present is supported by these studies. However, diagnostic overlaps of these two disorders cause confusion in the evaluation. For instance, it is possible that some of the children diagnosed with ADHD are actually suffering from $\mathrm{BAD}$ which would explain the increased rates of $\mathrm{BAD}$ within their family members.

\section{Neurobiological Studies}

Neurocognitive studies of patients with ADHD identified patterns of executive dysfunction in patients with ADHD that are thought to reflect abnormalities in the functioning of the prefrontal cortex, therefore supporting the hypothesis of an alteration of the prefrontal cortex neuroanatomy in ADHD (65-67). The most consistent structural brain imaging findings in children with ADHD have been significantly smaller volumes in the dorsolateral prefrontal cortex, caudate, pallidum, corpus callosum, and cerebellum. Similarly, BAD patients have shown differences in frontal, and temporal regions of the brain, and corpus callosum and basal ganglia, as well (68). Thus, similar areas of the brain were reported to be involved in both conditions with only the temporal lobe seeming to play a role in BAD alone. Although dysfunction of similar brain areas could suggest a relationship between $\mathrm{BAD}$ and $\mathrm{ADHD}$, it is important to recognize that these brain areas are not restricted to $\mathrm{BAD}$ and $\mathrm{ADHD}$ pathologies. In fact, the same areas appear to be activated differentially in a number of psychiatric 
conditions including anxiety disorders (69) and depression $(69,70)$. To our knowledge, no neuroimaging study has previously been conducted with ADHD, BAD, and ADHD/BAD patients concurrently.

Most studies have found abnormalities in cerebral activation in ADHD, with a hypoperfusion of frontal and possibly striatal areas (65-67,71-74). Several imaging studies using ligands highly selective for the dopamine transporter sites have studied their density in ADHD subjects compared to controls. Dopamine transporter and the dopamine seem to play important roles in the pathophysiology of ADHD and in response to its treatment. These studies consistently found an increase in binding of dopamine transporter in the striatum of ADHD subjects compared to controls. Several studies also showed a normalization of this brain function following treatment with methylphenidate (75-78). Pharmacological treatments for both ADHD and BAD act on the dopaminergic, noradrenergic and serotonergic systems. ADHD is usually treated with stimulants whereas BAD treatment involves either mood stabilizers, including anticonvulsants, antipsychotics, lithium, and sometimes; antidepressants.

The fact that similar classes of medications can treat both conditions suggests that ADHD and BAD could involve dysfunctions of the same neurotransmitters. However, this finding is not specific to these two conditions as dopamine and serotonin systems are also involved in several other psychiatric disorders (32).

\section{Clinical Conditions}

Studies about comorbidity report that the association of BAD/ADHD lead to significant socioeconomic and clinical results $(7,34,79,80)$.

It has been proposed that $\mathrm{BAD}$ affects the patient's marriage and occupational life and leads to severe and rather persistent disorders (79). Coryell et al. (79) followed up 48 patients with BAD for 6 years and compared them with normal controls in their study. They found that these patients could not develop their education and occupational states and were unemployed at a significantly higher rate in the last year of the follow-up. Although coupled with normal controls of the same age, their marriage rates were decreased by half and rates of divorce and separation were found to be 2 fold higher
(79). Again, studies have shown that adults with ADHD had a lower socioeconomic status, experienced problems in their occupational life, changed work more frequently, had a shorter educational life and a lower academic success, repeated classes more frequently, matured more lately and experienced more problems in their marriages $(49,81,82)$. Attention deficit, impulse control disorder and disruption in social communication observed in ADHD disrupt academic and professional performance $(83,84,85)$ and driving performance $(82,86)$. Negative life events are observed at a higher rate in individuals with ADHD in all ages compared to controls $(87,88)$. These negative life events were found to be related to the severity of ADHD in adults (45). In addition, these negative life events are also related to other negative results including hopelessness, suicidal thought, incompatibility, loss of environmental control (89).

BAD starts at a significantly earlier age in patients with BAD+ADHD compared to patients without ADHD $(7,11,23,43,47,54)$. In the study performed by Nierenberg et al. (11), $60 \%$ of the patients had early onset BAD. Data suggest that early-onset BAD may be related to ADHD (8). Nierenberg et al. (11) report that the age of onset of $B A D$ is critically important and proposed that $\mathrm{BAD}+\mathrm{ADHD}$ is a subtype starting in the early childhood and this may be a different condition from BAD which classically starts in the adulthood (43). Familial studies conducted on this subject support this (32).

In addition, BAD proceeded more chronically and with disability in individuals with a comorbidity of $\mathrm{BAD} /$ ADHD compared to the ones without comorbidity of $\mathrm{BAD} / \mathrm{ADHD}$. Shorter time of wellbeing and shorter intervals between attacks were related to higher number of attacks (11).

Tamam et al. (7) found the total number of attacks to be statistically higher in the $\mathrm{BAD}+\mathrm{ADHD}$ group in the study they performed in 159 bipolar patients. When the patients were examined in terms of the first attack, some studies did not find a difference in terms of the characteristics of the first attack $(7,11,23)$, but some other studies reported that manic and depressive episodes were observed at a higher rate in these patients and the number of days with irritability was higher $(10,11)$.

Suicidal attempts were observed at a higher rate in these patients and legal problems were increased (11). In patients with a comorbidity of BAD and ADHD, increase 
in attention deficit was related to anxiety and alcohol and substance abuse and addiction $(7,11,44)$. Alcohol and substance abuse was reported to be high in individuals with both BAD $(90,91)$ and ADHD. Familial studies show that symptoms of ADHD are observed at a high rate in adults with alcohol addiction (92). Symptoms of ADHD were also found at a higher rate in children of individuals with alcohol addiction compared to the control group. In addition, rates of both ADHD and substance abuse were found to be high in adolescent or adult children of individuals with substance abuse $(86,92,93)$.

Association of these two conditions affects the quality of life negatively. Global Assessment of Functioning (GAF) scores are statistically significantly lower in patients with a co-diagnosis of BAD/ADHD compared to patients with only ADHD (44).

\section{References:}

1. Günay Ş, Savran C, Aksoy UM, Maner F, Turgay A, Yargıç İ. Erişkin Dikkat Eksikliği Hiperaktivite Ölçeğinin (Adult ADD/ ADHD DSM-IV Based Diagnostic Screening and Rating Scale) Dilsel Eşdeğerlilik, Geçerlik Güvenirlik ve Norm Çalıșması Türkiye'de Psikiyatri 2006;8:98-107.

2. Cheon KA, Ryu YH, Kim YK, Namkoong K, Kim CH, Lee JD. Dopamine transporter density in the basal ganglia assessed with [123I] IPTSPECT in children with attention deficit hyperactivity disorder. Eur J Nucl Med Mol Imaging 2003;30:306-311.

3. Weissman MM, Bland RC, Canino GJ, Faravelli C, Greenwald S, Hwu HG, Joyce PR, Karam EG, Lee CK, Lellouch J, Lepine JP, Newman SC, Rubio -Stipec M, Wells JE, V Vickramaratne PJ, Wittchen H, Yeh EK. Cross-national epidemiology of major depression and bipolar disorder. JAMA 1996;276:293-299.

4. Bebbington P, Ramana R. The epidemiology of bipolar disorder. Sos Psychiatry Epidemiology 1995;30:279-92.

5. Akiskal HS, Bourgeois ML, Jules Angst, Post R, Moller H, Hirshfeld R. Reevaluating the prevalance of and diagnostic composition within the broad clinical spectrum of bipolar disorders. Journal of Affective Disorders 2000;59:5-30.

6. Akiskal HS. The bipolar spectrum: research and clinical perspectives. Encephale. 1995;21:3-11.

7. Tamam L, Karakus G, Ozpoyraz N. Comorbidity of adult attentiondeficit hyperactivity disorder and bipolar disorder: prevalence and clinical correlates. Eur Arch Psychiatry Clin Neurosci 2006;258:385393.

8. Winokur G, Coryell W, Endicott J, Akiskal H. Further distinctions between manic-depressive illness (bipolar disorder) and primary depressive disorder (unipolar depression). Am J Psychiatry 1993;150:1176-81.

\section{CONCLUSION}

In conclusion, when taken all together, all these evidences strongly suggest that ADHD and BAD are correlated and even that ADHD/ BAD might constitute a separate condition. Surely, chance alone cannot explain these findings in a satisfactory manner. On the other hand, the results of some studies support the view that these two conditions are interlocked with each other and are the same entity. Methodological difficulties prevent designing a study, which will help us understand, if these two conditions are separate entities or a spectrum. However, additional studies are clearly needed to determine whether the link between ADHD and BAD resides only at the epidemiological level or also at the clinical and biological level.

9. Tamam L, Tuğlu C, Karatas G, Ozcan S. Adult attention-deficit hyperactivity disorder in patients with bipolar I disorder in remission: preliminary study. Psychiatry Clin Neurosci 2006;60:480-5.

10. Wilens TE, Dodson W. A clinical perspective of attentiondeficit/hyperactivity disorder into adulthood. J Clin Psychiatry 2004;65:1301-13.

11. Nierenberg AA, Miyahara S, Spencer T, et al. Clinical and diagnostic implications of lifetime attention-deficit/hyperactivity disorder comorbidity in adults with bipolar disorder: data from the first 1000 STEP-BD participants. Biol Psychiatry 2005;57:1467-1473.

12. Sentissi O, Navarro JC, Oliveira HD, Gourion D, Bourdel MC, Baylé FJ, Olié JP, Poirier MF. Bipolar disorders and quality of life: the impact of attention deficit/hyperactivity disorder and substance abuse in euthymic patients. Psychiatry Res 2008 Oct 30;161:36-42.

13. Polanczyk G, Silva de Lima M, Horta BL, Biederman J, Rohde LA The worldwide Prevalence of ADHD: A Systematic Review and Metaregression Analysis. Am J Psychiatry 2007;164:942-948.

14. Weiss M, Weiss G. Attention defict hyperactivity disorder. In Child and Adolescent Psychiatry, A Comprehensive Textbook. Lewis EM (editor). $3^{\text {rd }}$ ed. Philadelphia, Lippincott Williams Wilkins, 2002:645-670

15. Kessler RC, Adler L, Barkley R, Biederman J, Conners CK, Demler O, Faraone SV, Greenhill LL, Howes MJ, Secnik K, Spencer T, Ustun TB, Walters EE, Zaslavsky AM. The prevalence and correlates of adult ADHD in the United States: results from the National Comorbidity Survey Replication. Am J Psychiatry 2006;163:716-23.

16. Kooij JJ, Buitelaar JK, van den Oord EJ, et al. Internal and external validity of attention-deficit hyperactivity disorder in a populationbased sample of adults. Psychol Med 2005;35:817-827. 
17. Fayyad J, DeGraaf R, Kessler R, Alonso J, Angermeyer M, Demyttenaere K, et al. Cross-national prevalence and correlates of adult attention-deficit hyperactivity disorder. Br J Psychiatry 2007;190:402-9.

18. Faraone SV, Biederman J. What is the prevalence of adult ADHD? Results of a population screen of 966 adults. J Atten Disord 2005;9:384-391.

19. Rasmussen P, Gillberg C. Natural outcome of ADHD with developmental coordination disorder at age 22 years: a controlled, longitudinal, community-based study. J Am Acad Child Adolesc Psychiatry 2000;39:1424-31.

20. Murphy KR, Barkley RA, Bush T. Young adults with attention deficit hyperactivity disorder: subtype differences in comorbidity, educational, and clinical history. J Nerv Ment Dis 2002;190:147-57.

21. Sobanski E. Psychiatric comorbidity in adults with attentiondeficit/hyperactivity disorder (ADHD). Eur Arch Psychiatry Clin Neurosci 2008;258:192-3.

22. Kooij JJ, Burger H, Boonstra AM, Van der Linden PD, Kalma LE, Buitelaar JK. Efficacy and safety of methylphenidate in 45 adults with attention-deficit/hyperactivity disorder. A randomized placebo-controlled double-blind cross-over trial. Psychol Med 2004;34:973-82.

23. Karaahmet E. Bipolar Afektif Bozukluğu Olan Hastalarda Erişkin Tipi Dikkat Eksikliği ve Hiperaktivite Bozukluğunun Yaygınlığı. Yayımlanmamış Uzmanlık Tezi, Zonguldak Karaelmas Üniversitesi Tıp Fakültesi, Psikiyatri AD, Zonguldak 2009.

24. Tuğlu C, Şahin ÖÖ. Erișkin Dikkat Eksikliği Hiperaktivite Bozukluğu: Nörobiyoloji, Tanı Sorunları ve Klinik Özellikler. Psikiyatride Güncel Yaklaşımlar 2010;2:75-116.

25. Biederman J, Faraone SV, Spencer T, Wilens T, Mick E, Lapey KA. Gender differences in a sample of adults with attention deficit hyperactivity disorder. Psychiatry Res 1994;53:13-29.

26. Biederman J, Faraone SV, Spencer T, Wilens T, Norman D, Lapey KA, Mick E, Lehman BK, Doyle A. Patterns of psychiatric comorbidity, cognition, and psychosocial functioning in adults with attention deficit hyperactivity disorder. Am J Psychiatry 1993;150:1792-8.

27. Jensen PS, Martin D, Cantwell DP . Comorbidity in ADHD: implications for research, practice, and DSM-V. J Am Acad Child Adolesc Psychiatry 1997;36:1065-79.

28. Klassen LJ, Katzman MA, Chokka P. Adult ADHD and its comorbidities, with a focus on bipolar disorder. J Affect Disord 2010;124:1-8.

29. Milberger S, Biederman J, Faraone SV, Murphy J, Tsuang MT. Attention deficit hyperactivity disorder and comorbid disorders: Issues of overlapping symptoms. Am J Psychiatry 1995;152:17931800.

30. Galanter C, Pagar D, Davies M, Li W, Carlson G, Abikoff H, Eugene Arnold L, Bukstein O, Pelham W, Elliott G, Hinshaw S, Epstein J, Wells K, Hechtman LH, Newcorn J, Greenhill L, Wigal T, Swanson J, Jensen P. ADHD and manic symptoms: diagnostic and treatment implications. Clinical Neuroscience Research 2005;5:283-294.

31. Adler LA, Florence M (editors). Scattered Minds. New York, NY: Putnam 2006:11-35.
32. Kent L, Craddock N. Is there a relationship between attention deficit hyperactivity disorder and bipolar disorder? Journal of Affective Disorders 2003;73:211-221.

33. Galanter CA, Leibenluft E. Frontiers between attention deficit hyperactivity disorder and bipolar disorder. Child and Adolescent Psychiatric Clinics of North America 2008;17:325-346.

34. Wingo AP, Ghaemi SN. A systematic review of rates and diagnostic validity of comorbid adult attention-deficit/hyperactivity disorder and bipolar disorder. The Journal of Clinical Psychiatry 2007;68:1776-1784.

35. Reichenberg A, Weiser M, Rabinowitz J, Caspi A, Schmeidler J, Mark M, Kaplan Z, Davidson M. A population-based cohort study of premorbid intellectual,language, and behavioral functioning in patients with schizophrenia, schizoaffective disorder, and nonpsychotic bipolar disorder. The American Journal of Psychiatry 2002;159:2027-2035

36. Brassett-Harknett A, Butler N. Attention-deficit/hyperactivity disorder: an overview of the etiology and a review of the literature relating to the correlates and life course outcomes for men and women. Clinical Psychology Review 2007;27:88-210.

37. Öncü B, Ölmez Ş, Ștürk V. Wender-Utah Derecelendirme Ölçeği Türkçe Formunun Erişkin Dikkat Eksikliği Ve Hiperaktivite Bozukluğu'nda Geçerlik ve Güvenilirlik Çalışması. Türk Psikiyatri Dergisi 2005;16:252-259.

38. Barkley RA, Murphy KR, Kwasnik D. Motor vehicle driving competencies and risks in teens and young adults with attention deficit hyperactivity disorder. Pediatrics 1998;98:1089-1095.

39. Hantouche EG, Akiskal HS, Lancrenon S, Allilaire JF, Sechter D, Azorin JM, Bourgeois M, Fraud JP, Chatenet-Duchene L. Systematic clinical methodology for validating bipolar-II disorder: data in mid-stream from a French national multi-site study (EPIDEP). Journal of Affective Disorders 1998;50:163-173.

40. Judd LL, Akiskal HS, Schettler PJ, Coryell W, Endicott J, Maser JD, Solomon DA, Leon AC, Kelle MB. A prospective investigation of the natural history of the long-term weekly symptomatic status of bipolar II disorder. Archives of General Psychiatry 2003;60:261269.

41. Mannuzza S, Klein RG, Klein DF, Bessler A, Shrout P. Accuracy of adult recall of childhood attention deficit hyperactivity disorder. Am J Psychiatry 2002;159:1882-1888.

42. Berkson S. Limitations of the application of fourfold table analysis to hospital data. Biometrics Bulletin 1996;2:47-53:1946

43. Sachs GS, Baldassano CF, Truman CJ, Guille C. Comorbidity of attention deficit hyperactivity disorder with early- and late-onset bipolar disorder. Am J Psychiatry 2000;157:466-68.

44. Wilens TE, Biederman J, Wozniak J, Gunawardene S, Wong J, Monuteaux M. Can adults with attention-deficit/hyperactivity disorder be distinguished from those with comorbid bipolar disorder? Findings from a sample of clinically referred adults. Biol Psychiatry 2003;54:1-8.

45. Garcia CR, Bau CH, Silva KL, Callegari-Jacques SM, Salgado CA, Fischer AG, Victor MM, Sousa NO, Karam RG, Rohde LA, Belmonte-de-Abreu P, Grevet EH. The burdened life of adults with ADHD:Impairment beyond comorbidity. Eur Psychiatry 2010 (in press). 
46. West SA, McElroy SL, Strakowski SM, Keck PE Jr, McConville BJ. Attention deficit hyperactivity disorder in adolescent mania. Am J Psychiatry 1995;152:271-3.

47. West SA, Strakowski SM, Sax KW, McElroy SL, Keck PE Jr, McConville BJ. Phenomenology and comorbidity of adolescents hospitalized for the treatment of acute mania. Biol Psychiatry 1996;39:458-60.

48. Geller B, Williams M, Zimerman B, Frazier J, Beringer L, Warner KL. Prepubertal and early adolescent bipolarity differentiate from ADHD by manic symptoms, grandiose delusions, ultra-rapid or ultradian cycling. J Affect Disord 1998;51:81-91.

49. Faraone SV, Biederman J, Wozniak J, Mundy E, Mennin D, O'Donnell D. Is comorbidity with ADHD a marker for juvenileonset mania? J Am Acad Child Adolesc Psychiatry 1997;36:1046-55.

50. Biederman J, Faraone SV, Mick E, Wozniak J, Chen L, Ouellette C, Marrs A, Moore P, Garcia J, Mennin D, Lelon E. Attention deficit hyperactivity disorder and juvenile mania: an overlooked comorbidity? J Am Acad Child Adolesc Psych 1996b;35:997-1008.

51. Biederman J, Faraone SV, Mick E, et al. Attention-deficit hyperactivity disorder and juvenile mania: an overlooked comorbidity? J Am Acad Child Adolesc Psychiatry 1996;35:9971007.

52. Klein RG, Pine DS, Klein DF. Resolved: mania is mistaken for ADHD in prepubertal children: negative. J Am Acad Child Adolesc Psychiatry 1992;37:1093-1096.

53. Stein MA, Roizen NM, Leventhal BL. Bipolar disorder and ADHD. J Am Acad Child Adolesc Psychiatry 1999;38:1208-1209.

54. Biederman J, Mick E, Faraone SV. Age-dependent decline of symptoms of attention deficit hyperactivity disorder: impact of remission definition and symptom type. Am J Psychiatry 2000;157:816-818.

55. Diler RS, Uguz S, Seydaoglu G, Erol N, Avci A. Differentiating bipolar disorder in Turkish prepubertal children with attentiondeficit hyperactivity disorder. Bipolar Disord 2007;9:243:251.

56. Wozniak J, Biederman J, Kiely K, Ablon JS, Faraone SV, Mundy E, Mennin D. Mania-like symptoms suggestive of childhood-onset bipolar disorder in clinically referred children. J Am Acad Child Adolesc Psychiatry 1994;34:867-76.

57. Jaideep T, Reddy YCJ, Srinath S. Comorbidity of attention deficit hyperactivity disorder in juvenile bipolar disorder. Bipolar Disord 2006;8:182-187.

58. Srinath S, Janardhan Reddy YC, Girimaji SR, Seshadri SP, Subbakrishna DK. A prospective study of bipolar disorder in children and adolescents from India. Acta Psychiatr Scand 1998;98:437-442.

59. Kim-Cohen J, Caspi A, Moffitt TE, Harrington H, Milne BJ, Poulton R. Prior juvenile diagnoses in adults with mental disorder: developmental follow-back of a prospective-longitudinal cohort. Arch Gen Psychiatry 2003;60:709-17.

60. Craddock N, Jones I. Genetics of bipolar disorder. J Med Genet 1999;36:585-94.

61. Faraone SV, Doyle AE. The nature and heritability of attentiondeficit/ hyperactivity disorder. Child Adolesc Psychiatr Clin North Am 2001;10:299-316.
62. Faraone SV, Biederman J, Mennin D, Wozniak J, Spencer T. Attention-deficit hyperactivity disorder with bipolar disorder: a familial subtype? J Am Acad Child Adolesc Psychiatry 1997b;36:1378-1390.

63. Chang KD, Steiner H, Ketter TA. Psychiatric phenom enology of child and adolescent bipolar offspring. J Am Acad Child Adolesc Psychiatry 2000; 39:453-460.

64. Adler LA. Best practices in adult ADHD: special considerations. CNS Spectr 2008;13:4.

65. Rubia K, Overmeyer S, Taylor E, Brammer M, Williams SC, Simmons A, Bullmore ET. Hypofrontality in attention deficit hyperactivity disorder during higher-order motor control: a study with functional MRI. Am J Psychiatry 1999;156:891-896.

66. Bush G, Frazier JA, Rauch SL, Seidman LJ, Whalen PJ, Jenike MA, Rosen BR, Biederman J. Anterior cingulate cortex dysfunction in attention-deficit/hyperactivity disorder revealed by fMRI and the counting stroop. Biol Psychiatry 1999;45:1542-1552.

67. Teicher MH, Anderson CM, Polcari A, Glod CA, Maas LC, Renshaw PF. Functional deficits in basal ganglia of children with attentiondeficit/ hyperactivity disorder shown with functional magnetic resonance imaging relaxometry. Nat Med 2000;6:470-473.

68. Videbech P. MRI findings in patients with affective disorder: a metaanalysis. Acta Psychiatr Scand 1997;96:157-168.

69. Brambilla P, Barale F, Caverzasi E, Soares JC. Anatomical MRI findings in mood and anxiety disorders. Epidemiol Psychiatr Soc 2001;11:88-99

70. Drevets WC. Functional anatomical abnormalities in limbic andprefrontal cortical structures in major depression. Prog Brain Res 2000;126:413-431.

71. Yang $\mathrm{P}$, Wang $\mathrm{PN}$, Chuang $\mathrm{KH}$, et al. Absence of gender effect on children with attentiondeficit/hyperactivity disorder as assessed by optimized voxelbased morphometry. Psychiatry Res 2008;164:245-253.

72. Anderson CM, Polcari A, Lowen SB, Renshaw PF, Teicher MH. Effects of methylphenidate on functional magnetic resonance relaxometry of the cerebellar vermis in boys with ADHD. Am J Psychiatry 2002;159:1322-1328.

73. Durston S. A review of the biological bases of ADHD: What have we learned from imaging studies? Ment Retard Dev Disabil Res Rev 2003;9:184-195.

74. Durston S, Tottenham NT, Thomas KM, Davidson MC, Eigsti IM, Yang Y, et al. Differential patterns of striatal activation in young children with and without ADHD. Biol Psychiatry 2003;53:871-878.

75. Dougherty DD, Bonab AA, Spencer TJ, Rauch SL, Madras BK, Fischman AJ. Dopamine transporter density in patients with attention deficit hyperactivity disorder. Lancet 1999;354:2132-2133.

76. Spencer T. Invivo neuro receptor imaging of attention-deficit/ hyperactivity disorder: A focus on the dopamine transporter. Biol Psychiatry 2005;57:1293-1300.

77. Spencer TJ, Biederman J, Ciccone PE, Madras BK, Dougherty DD, Bonab AA, Livni El, Parasrampuria DA, Fischman AJ. PET study examining pharmacokinetics, detection and likeability, and dopamine transporter receptor occupancy of short-and longacting oral methylphenidate. Am J Psychiatry 2006;163:3;387-395. 
78. Jucaite A, Fernell E, Halldin C, Forssberg H, Farde L. Reduced midbrain dopamine transporter binding in male adolescents with attention-deficit/hyperactivity disorder: Association between striatal dopamine markers and motor hyperactivity. Biol Psychiatry 2005;57:229-238.

79. Coryell W, Scheftner WA, Keller $M$ and at al. The enduring psychosocial coneguences of mania and depresion. Am J Psychiatry 1993;150:703-720.

80. Masi G, Perugi G, Toni C, Millepiedi S, Mucci M, Bertini N, Pfanner C. Attention-deficit hyperactivity disorder bipolar comorbidity in children and adolescents. Bipolar Disord 2006; 8:373-81.

81. Faraone SV, Sergeant J, Gillberg C, Biederman J. The worldwide prevalence of ADHD: is it an American condition? World Psychiatry 2003;2:104-113.

82. Murphy, K. \& R.A Barkley. Attention deficit hyperactivity disorder adult: Comorbidities and adaptive impairments. Comp. Psychiatry 1996;37:393-401.

83. Able SL, Johnston JA, Adler LA, Swindle RW. Functional and psychosocial impairment in adults with undiagnosed ADHD. Psychol Med 2007;37:97-107.

84. Biederman J, Monuteaux MC, Mick E, Spencer T, Wilens TE, Silva JM. Young adult outcome of attention deficit hyperactivity disorder: acontrolled-10year follow-upstudy. Psychol Med 2006;36:67-79.

85. LoeI M, Feldman HM. Academic and educational outcomes of children with ADHD. Ambul Pediatr 2007;7:82-90.
86. Barkley RA, Cox D. A review of driving risks and impairments associated with attention-deficit/hyperactivity disorder and the effects of stimulant medication on driving performance. J Safety Res 2007;38:113-28.

87. Muller DJ, Mandelli L, Serretti A, DeYoung CG, DeLuca V, Sicard T. Serotonin transporter gene and adverse life events in adult ADHD. Am J Med Genet B Neuropsychiatr Genet 2008;147:1461-9.

88. Tillman R, Geller B, Nickelsburg MJ, Bolhofner K, Craney JL, DelBello MP, et al. Life events in a prepubertal and early adolescent bipolar disorder phenotype compared to attentiondeficit hyperactive and normal controls. J Child Adolesc Psychopharmacol 2003;13:243-51.

89. Sarason IG, Johnson JH, Siegel JM. Assessing the impact of life changes: development of the Life Experiences Survey. J Consult Clin Psychol 1978;46:932-46.

90. Cornelius JR, Clark DB, Bukstein OG, Salloum IM. Treatment of co-occurring alcohol, drug, and psychiatric disorders. Recent Dev Alcohol 2005;17:349-65.

91. Brady KT, Myrick H, Henderson S, Coffey SF. The use of divalproex in alcohol relapse prevention: a pilot study. Drug Alcohol Depend 2002;1;67:323-30.

92. Sullivan MA, Rudnik-Levin F. Attention deficit/hyperactivity disorder and substance abuse. Diagnostic and therapeutic considerations. Ann N Y Acad Sci 2001;931:251-70.

93. Tamam L. Bipolar Bozukluk ile Anksiyete Bozuklugu Birlikteligi: Bir Gözden Geçirme . Türk Psikiyatri Dergisi 2007;18:59-71. 